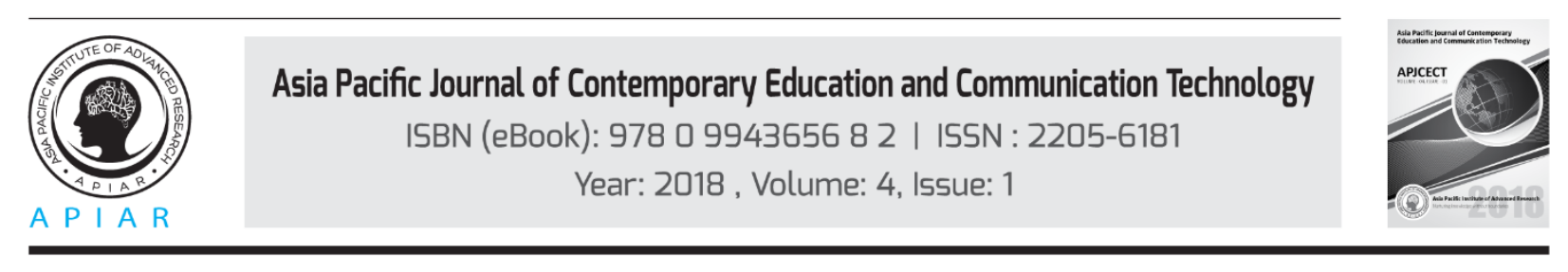

\title{
THE DEVELOPMET OF POCKET BOOK AS LEARNING MEDIA TO MAKE BATIK JUMPUT IN MULTICULTURAL ARTS AND SCARF SUBJECT
}

\author{
Faris Nur Khulafa ${ }^{a}$, Pria Santosa ${ }^{b}$ \\ ab Universitas Negeri Semarang, Semarang, Indonesia \\ Corresponding email: khulafafaris@gmail.com
}

\begin{abstract}
Based on observations in the fifth grade of Lab-School UNNES elementary school (through tests, interviews, and the administration of questionnaires) students have difficulties in learning to make batik jumput in Multicultural Arts and Scarf (which is called SBK). Data showed that 22 out of a total of 47 learners had already completed the minimum criteria ( usually known as KKM). It could be said that $46 \%$ of learners have reached the KKM and the remaining 54\% haven't reached the KKM. To overcome these problems, the researcher developed a pocket book. The subject of research comprises of students and teacher in class V of Lab-School UNNES elementary school, Gajahmungkur sub-district, Semarang. The Number of students are 47 consisting of 23 students pesera class VA and for VB grade and 24 learners. Data collection techniques are tests of performance and non-test techniques. The data analysis used validity, reliability, normality and N - gain. Data collection techniques used in this research were nontest techniques and tests. The data analysis used validity, reliability, normality and $\mathrm{N}-$ gain. The results showed: 1) based on the now great need of assessment obtained as a pocket book as a media of learning making batik jumput;2) based on the expert assessment material, media experts and linguists, the pocket book meets the criteria of decent use in learning and 3) Pocket Book was solution over the index KKM on subjects SBK material which made batik jumput evidenced by increased n-gain in the amount of 0.52. Conclusions from this research is that pocket book, as learning media to make batik jumput in SBK subject in the fifth grade LabSchool UNNES elementary school, is feasible to use and improve learning outcomes.
\end{abstract}

Keywords: Pocket Book; Fifth Grade; Multicultural Art and Scarf; Media Development.

\section{Introduction}

The regulation of National Education Ministry as cited by Permendiknas (2006), Standards of Content stated that Educational Unit-based Curriculum (KTSP) consists of all the components of competences in subjects, local content, and self-development. One of the subjects that stated in that regulation is Multicultural Art and Craft (or usually called SBK) is essentially an art education-based culture that includes: fine arts, music, dance, art and skills. Art education as stated in Susanto \& Ahmad, (2013, p. 261) and is one of determining factors in shaping the personality of the child. SBK education in elementary school have a function and purpose to develop attitudes and improve psychomotor skills. It has a role in the formation of private learners harmonious, having regard to the developmental needs of the child in achieving multiintelligence consisting of intrapersonal intelligence, interpersonal, visual, musical, linguistic, logical, mathematical, naturalistic, and intelligence of creativity, intelligence, spiritual, moral and emotional intelligence. 
In Learning SBK, it is necessary to select methods and media that will impact the effectiveness of the achievement of learning competencies that have been set. Availability of facilities such as a learning media is needed by the teacher in designing and implementing learning. One of the basic competencies that must be taught in SBK subjects in primary school is batik ikatcelup. Batik ikatcelup or known as batik jumput is the process of making decorative and color on a white cloth using tie-dye technique, binding it with string or rubber bands, subsequently dyed on fabric dyes for example remasol(Satmowi, 1990, p. 20).

The implementation of Batik Jumput learning of Grade V in Lab school UNNES elementary school. There is not any learning media that is used by teacher while carrying out a learning activity. The result of Observation in the form of interviews with teachers presents that there is a need for media that is interesting, easy to use, practical, easy to understand and equipped with image. The researcher designed it to develop a learning media to overcome the problem, for the use the media affects both the learning process and learning outcome.

There are various kinds of media, and the researcher would develop a pocket book. It is a process to make the small pocket book that can be placed into the pocket and easy to carry anywhere, with short description reading using attractive fonts and backgrounds. Pocket Books developed concepts and presents a summary of the material, the steps make batik jumput accompanied by pictures, a brief description of each drawing tutorial, as well as the other components listed in the pocket book as the assignment of performance etc. The aim of this study is to develop a proper learning media for the material of making batik jumput and as solution to improve student's psychomotor skill and student's learning outcome.

\section{Methodology}

The type of research used is the developmental research (Research and Development). According to Sugiyono, (2014, p. 297) methods of research and development is the research methods used to produce a specific product and test the effectiveness of the product. Experimental design used in testing the product is the One-Shot Case Study.

Methods of research and development could be defined as the scientific method for researching, designing, producing and testing the validity of a product that has been produced. Based on such understanding, research and development activities are research, Design, production, and testing. In the current study, develop pocket book as learning media making batik jumput in Multicultural Art and Scarft in class V SD Lab school UNNES.

Step-by-step development of pocket book as learning media making batik jumput in Multicultural Art and Scarf in will be done as follows Anon., (2015, p. 409) the potential and problems, (2) data collection, (3) the design of the product (4) design validation, (5) product revision I, (6) testing products, (7) product revision II, (8) trial usage, (9) revision of the product, and (10) of the final product.

The subject of research students and teacher in class V SD Labscholl UNNES, Gajahmungkur subdistrict, Semarang, material expert, media expert and linguits. Number of students is 47, consisting of 23 students class VA and 24 students class VB. The teachers were chosen to be the subjects in order to do the need analysis upon the media of it. The experts were responsible to test the validity and readability of the developed media. They are the media experts, material experts and the linguits.

The research is taken in every semester, from academic year 2015/2016 in February-May 2016. The variables of this research is the design development of media pocket books, effectiveness of 
pocket books as media and learning outcomes of students in learning to make batik jumput with the pocket book as guide.

The research sample comprised of 47 students class VA and VB in elementary Lab school UNNES taken with saturated samples. Data collection techniques are tests of performance and non-test technique consists of interviews, questionnaires, and documentation. The validity used product moment formula and reliability used inter-rater test. The data analysis in the study consist of validating data analysis of a pocket book, the initial data analysis to test the normality using the lilieforse test, the final data analysis which consists of an average increase test using gain, analysis of learning outcomes of students making batik jumput, data analysis of participants' responses, and analysis of the results of the performance of learners.

\section{Results}

The result of the research includes the needs analysis of the students and teachers, the score of the operational field test of the media, the scoring from material experts, media design, visibility of media, efficiency of the media (shown from the result of the cognitive learning of students), and data analysis. The followings are the result of the study

a). The Needs of Students and Teachers

Based on information of the student's need, we can conclude the need for new learning media that contains images, a brief description, a summary of the material and personal notes, as well as the design that is practical and easy to use. The advice given by the teacher in the development of media that will be made as follows: (1) the design of media made interesting (2) media that will be developed is easy to use and practical and easy to understand, (3) the media that will be developed are equipped with image.

a. Design of Media

Media designed using CorelDraw application $\mathrm{X}_{7}$, the reason is because the media that is developed by researcher is small and practical i.e. pocket book. Media was designed as much as possible and includes all the needs of learners and teachers according to the questionnaire needs.

Figure 1 : Design of Pocket Book
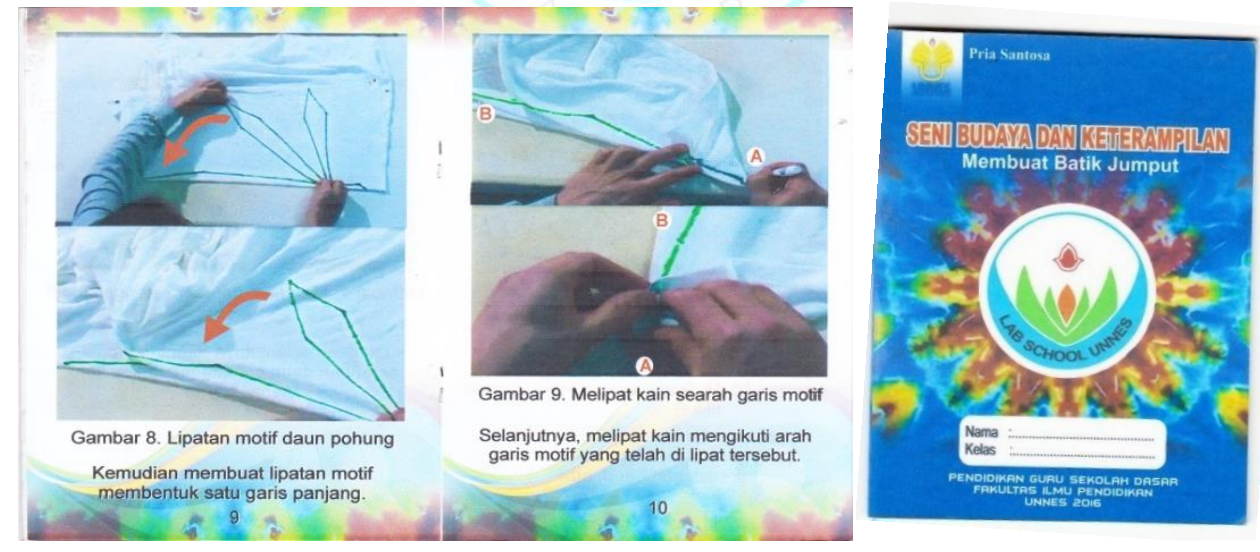

b. Results of FeasibilityAssessment of Pocket Book

The results of the assessment of the feasibility of the pocket book making batik jumput in class V Elementary School Labschool UNNES includes the assessment of media, content and language by a team of experts. 


\section{a). Material Assessment}

In this study, researchers collaborated with a professor who's an expert to assess and provide feedback or recommendations to make products developed deserves to be tested on a small scale and large scale. In accordance with the results of the assessment by the material expert, pocket book's material meets the criteria and is very decent on the material with a value of $98 \%$.

b). Media Assessment

In accordance with a recap of the results of the assessment by expert media, pocket book's material makes batik jumput meet the criteria of very decent on aspects of media with a percentage of $95 \%$.

c). Language Assessment

The recap of assessment results by linguists, the pocket book of making batik jumput meets the criteria, it deserves the linguistic aspect with percentage $73 \%$. Based on the assessment results by material expert, media expert and linguists, it could be concluded that the pocket book deserves to be tested in learning to make batik jumput in Multicultural Arts and Scarf Subject in class V Labschool UNNES Elementary School.

\section{c. The Results of Trial of Pocket Book as Learning Media}

Based on the trial of pocket book, the result noted that there is an increase in the average value after using the initially 66.36 became 83.98 . The minimum criteria obtained in the classroom increased from $46 \%$ to $97 \%$ of the 47 students of class V Elementary School Labschool UNNES, Gajahmungkur subdistrict, Semarang. Here is a chart to see the results of the initial performance assessment (performance I) before using media pocket book SBK with the performance of II after using pocket book.

Table 1: The Average Rate Performance

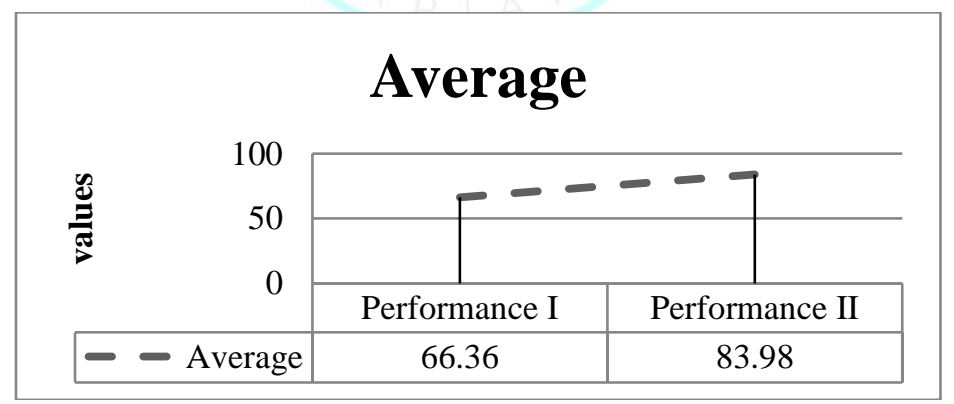

d. The Results of Performance Data Normality of I and II Test

Normality test is used to find out if these data have a normal distribution or not, assumption that normally distributed population help resolve the problem easily and smoothly. Normality test was calculated using Microsoft Office Excel 2007. The calculation of normality learning before and after using the pocket book as follows: 
Table 2:Normality Test Results

\begin{tabular}{|c|c|c|c|c|c|}
\hline Measures & $\begin{array}{l}\text { the } \\
\text { number } \\
\text { of } \\
\text { students }\end{array}$ & Average & $\begin{array}{l}\text { Standard } \\
\text { deviation }\end{array}$ & $\begin{array}{c}\text { Calculated } \\
\text { L }\end{array}$ & $\begin{array}{r}\text { Table } \\
\text { L }\end{array}$ \\
\hline $\begin{array}{l}\text { Perform } \\
\text { ance }\end{array}$ & 47 & 66.36 & 5.01 & 0.118 & 0.129 \\
\hline $\begin{array}{l}\text { Perform } \\
\text { ance }\end{array}$ & 47 & 83.98 & 6.37 & 0.088 & 0.129 \\
\hline
\end{tabular}

According to the table 4.11.it shows that calculated $\mathrm{L}<$ table $\mathrm{L}$ so that Ho is accepted, it can be concluded that the data were normally distributed.

e. Analysis of N-Gain

Analysis of N-gain was used to analyze the results of learning, that is to know the difference between the pretest and posttest. Then here is the data for the analysis of n-gain.

Table 3: TheResult of Analisys of Gain Score

\begin{tabular}{lc}
\hline & Score \\
\hline Average in pre-test & 83.98 \\
Average in post test & 66.36 \\
N-gain & 0.52 \\
\hline
\end{tabular}

Based on the analysis of N-gain values obtained 0:52 that is between the range from 0.3 to 0.7 which means that the entry in the medium category (Fauziah, 2010, p. 50). It can be concluded that the pocket books give positive effect on psychomotor skill in class $\mathrm{V}$ and effectively used in learning to make batik jumput on the subjects of Multicultural Arts and Scarf.

\section{Discussion}

The discussion will further discuss evaluating the results of research in the form of research meaning and implications of the research results. Defining the result of the research covers characteristics and design, validation of the scoring of learning media, user's feedback, and learning outcomes in pretest and post-test.

Characteristics of learning media in development research are print-based media that are practical and easy to use by learners. The pocket book is included in the requirement of enrichment books containing motivation, summary material, guide to making batik jumput, assignment of performance and it is equipped with a picture and a brief description as well as a personal record sheet learners. The form is practical, easy to learn, and its portability makes this media in accordance with the wishes and needs of the students.

The material experts give $98 \%$ on the appropriateness of the media while the media experts give $95 \%$ on the same category, and the linguist give $73 \%$ on the linguistic aspect. Futhermore, based on the questionnaire responses that were given to students and teachers, this shows that the average response is $95.1 \%$. On the teaching and learning process, it was reported that the learning outcomes increased from 66.36 to 83.98 and the classical completeness rate increased from $46 \%$ to $97 \%$. So, it is concluded that the media is a decent media and also improve the learning outcomes. 
The research was supported by several studies that has been done before, such as Nurul, et al in 2013 "The Differences of Learning Outcomes Between using the Pocket Book and without a Pocket Book on circular motion Kinematics of material Class X". The study shows that there is a significant difference between the use of pocket book and without pocket book to the learning outcomes of students in the physics of matter kinematics Circular Motion class X. Other research that supports is research conducted by Nurul, et al (2013), "Development of Integrated IPA Bilingual pocket book with a theme of chemicals in life As learning materials in the Islamic Junior High School". Based on the results of the validation phase 1 and 2 as well as the results of the responses of the students and science teachers MTs, it can be concluded that the integrated IPA bilingual pocket book theme chemicals in life worth using as teaching materials and can affect learning outcomes of students.

Furthermore, a research conducted by Mucharommah Sartika Ami, Endang Susantini and Raharjo in 2012 "Development of Materials Handbook on Human Excretion system in Senior High School Class XI". The research shows that science pocket book eligible for use in learning, because research shows that the pocket book material Human Excretion system had good category. Other supporting research is conducted by Inayatul Fitriyah and Abdur Rahman As'ari, "Learning Media Development of pocket book Learning with surface area Material in Junior High School". The research shows that pocket books are worthy of being used as the media in learning activities. Other research studies that support this is carried out by Giuliani and Lina (2015) "development of the Global warming pocket book for Junior High School". The study results conclude that pocket book with global warming materials are developed and effectively used as learning materials. Further supporting research is conducted by Saras s. Qurrota'aini, entitled "Developing Accounting Pocketbook As A Medium Of Learning To Improve Students ' Learning Motivation Of Accounting of Second Grade Social Programs In Senior High School 5 Yogyakarta In Academic Year Of 2012/2013". Results of the assessment showed the students on the quality of products that have been tested.

\section{Conclusion}

The development of pocket book as learning media to make batik jumputin Multicultural Arts and Scarf Subject in the fifth grade Labschool UNNES elementary school resulted in the design of media development, and demonstrates the feasibility of using and able to improve student learning outcomes. Teachers are now increasingly required to be creative, and so do the student who are required to have a greater motivation to support learning activities with the media.

\section{Acknowledgments}

The researcher would like to thank Farid Ahmadi, M.Pd., Ph.D. as the supervisor who was willing to guide this paper. The preparation of this paper has been supported in part by Department of Elementary School Teacher Education, Universitas Negeri Semarang. 


\section{References}

i. $\quad$ Anon., 2015. Metode Penelitian dan Pengembangan. Bandung: Alfabeta.

ii. Fithriyah, I. \& As'ari, A. R., 2013. Pengembangan Media Pembelajaran Buku Saku Materi Luas Permukaan bangun Ruanguntuk Jenjang SMA. Jurnal Pendidikan Matematika..

iii. $\quad$ Rahmawati \& Laili, N., 2013. Pengembangan Buku Saku IPA Terpadu Bilingual dengan Tema Bahan Kimia dalam Kehidupan Sebagai Bahan Ajar di MTs. UNNES Science Education Journal, 2(1), pp. 157-164.

iv. Satmowi, 1990. Teknik Ikat dan Celup. Semarang: PT Surya Prabha.

v. Sugiyono, 2014. Metode Penelitian Kualitatif, Kuantitatif, dan RND. Bandung: Alfabeta CV.

vi. Sukirno, S. S. Q. d., 2013. Pocketbook as Media of Learning to Improve Students' Learning Motivation. Jurnal Pendidikan Akuntansi, 11(2), pp. 68-75.

vii. $\quad$ Sulistyani, N. H. D., 2013. Perbedaan Hasil Belajar Siswa antara Menggunakan Media Pocket Book pada Materi Kinematika Gerak Melingkar Kelas X. Jurnal Pendidikan Fisika, 1(1), p. 164. 